\title{
Identification and Partial Characterization of Angiogenesis Bioactivity in the Lower Respiratory Tract after Acute Lung Injury
}

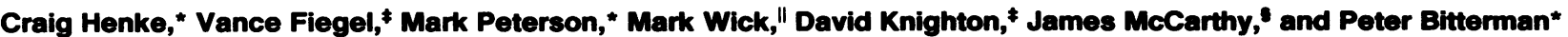 \\ ${ }^{*}$ Department of Medicine, ${ }^{ \pm}$Department of Surgery, ${ }^{8}$ Department of Laboratory Medicine and Pathology, University of Minnesota, \\ Minneapolis, Minnesota, 55455; and "Department of Pathology, Washington University, St. Louis, Missouri 63130
}

\begin{abstract}
Survival after acute lung injury (ALI) depends on prompt alveolar repair, a process frequently subverted by the development of granulation tissue within the alveolar airspace. Immunohistochemical examination of the intraalveolar granulation tissue confirmed that capillaries as well as myofibroblasts were the principal cellular constituents. We therefore hypothesized that angiogenesis factors would be present on the air-lung interface after ALI. To evaluate this hypothesis, bronchoalveolar lavage fluid from patients with ALI $(n=25)$ and patient controls $(n=8)$ was examined for angiogenesis bioactivity by its ability of induce endothelial cell migration. While lavage fluid from controls had no bioactivity, lavage fluid from $72 \%$ of patients with ALI promoted endothelial cell migration. Heparin affinity, ion exchange, and gel filtration chromatography resolved the bioactivity into at least two moieties. One appeared identical to the well characterized endothelial cell growth factor, basic fibroblast growth factor. The other was a 150-kD non-heparin binding protein that mediated endothelial cell migration and attachment in vitro, and the growth of new vessels in vivo. These data are consistent with the hypothesis that the growth of capillaries into the alveolar airspace results from angiogenesis factors present on the alveolar surface of the lung after ALI. (J. Clin. Invest. 1991. 88:1386-1395.) Key words: lung repair - granulation tissue - endothelial cell migration • angiogenesis $\bullet$ angiogenesis factors
\end{abstract}

\section{Introduction}

Acute lung injury is an abrupt alteration of the pulmonary parenchyma leading to functional impairment of the gas exchange apparatus. This disorder occurs after direct pulmonary injury such as aspiration of gastric contents, or after sepsis or trauma occurring in another part of the body. Despite significant advances in critical care technology, in its most fulminant form, the adult respiratory distress syndrome (ARDS), ${ }^{1}$ acute

Address correspondence and reprint requests to Dr. Craig A. Henke, Pulmonary Division, Department of Medicine, UMHC Box 276, University of Minnesota, 420 Delaware Street Southeast, Minneapolis, MN 55455. 1991.

Received for publication 9 October 1990 and in revised form 24 June

1. Abbreviations used in this paper: $\mathrm{ABC}$, avidin-biotin-peroxidase complex; ARDS, adult respiratory distress syndrome; bFGF, basic fibroblast growth factor; DEAE-S, diethylamino ethyl sepharose.

J. Clin. Invest.

(c) The American Society for Clinical Investigation, Inc.

$0021-9738 / 91 / 10 / 1386 / 10 \$ 2.00$

Volume 88, October 1991, 1386-1395 lung injury exacts a mortality in excess of $50 \%$. ARDS constitutes a major public health problem with an estimated 150,000 patients treated annually in the United States (1).

Anatomically, acute lung injury is an explosive transmural process. There is widespread death of the alveolar epithelium and microcirculatory endothelium as well as significant interstitial edema $(2,3)$. When alveolar repair is to be effective, a precisely coordinated sequence of cellular migration and replication reconstitutes the air-lung interface, interstitium, and blood-lung interface. The repair process, however, frequently fails. Under these circumstances, an acute fibroproliferative response ensues in which granulation tissue rapidly fills the alveolar airspace, precluding effective gas exchange (4).

While most attention has been focused on the role of the interstitial myofibroblast in the evolution of acute intra-alveolar granulation, new blood vessel growth is a prominent component of the fibroproliferative response (5). The development of new blood vessels is controlled by a discrete set of peptides, collectively referred to as angiogenesis factors $(6,7)$. For new blood vessels to grow into the alveolar airspace, microvascular endothelial cells must migrate through the injured alveolar wall and attach to the intra-alveolar provisional matrix. We therefore designed this study to examine the hypothesis that angiogenesis factors capable of stimulating endothelial cell migration and attachment would be present on the air-lung interface after acute lung injury. The data indicate that angiogenesis bioactivity was present in the lungs of most patients after acute lung injury. Two peptides accounted for the majority of the bioactivity. One had a molecular mass of $18 \mathrm{kD}$ and appeared identical to the established endothelial cell growth factor, basic fibroblast growth factor (bFGF). The other was a 150-kD molecule that stimulated directed migration and attachment of endothelial cells in vitro, angiogenesis in vivo, and appeared to be distinct from previously characterized angiogenesis factors.

\section{Methods}

\section{Study population}

Two groups of patients underwent bronchoscopy with bronchoalveolar lavage for the purpose of examining the air-lung interface for the presence of angiogenesis factors.

1. Acute lung injury $(n=25)$. Patients with severe acute lung injury being supported with mechanical ventilation who met the standard clinical criteria for ARDS were included in this cohort $(8,9)$. All patients had an appropriate antecedent history, severe hypoxemia despite high concentrations of supplemental oxygen, chest radiograph showing diffuse infiltrates, and no other explanation for their respiratory insufficiency. Patients were studied within $21 \mathrm{~d}$ of disease onset to obtain samples from the alveolar epithelial surface. A subset of acute lung injury patients who died from respiratory insufficiency 14 to $21 \mathrm{~d}$ after disease onset were evaluated post-mortem by ex vivo whole lung lavage to permit preparative biochemical studies. Most patients $(n=17)$ were studied early in their clinical course (day 2-4) as soon as bron- 
choalveolar lavage could be safely performed. The remainder of the patients $(n=8)$ were studied later in their clinical course (day 10-21) in order to provide samples which temporally corresponded to the postmortem whole lung lavage samples obtained for preparative biochemical examination.

2. Patient controls $(n=8)$. This group consisted of normal individuals and patients undergoing bronchoscopy for evaluation of a localized process. Bronchoalveolar lavage was performed in an area distant from the lesion.

\section{Immunohistochemistry}

Representative lung tissue was obtained at autopsy from patients who died of acute lung injury $(n=12)$, as well as 10 control cases with no pulmonary abnormalities. The tissue was fixed in $10 \%$ neutral-buffered formalin for 6 to $18 \mathrm{~h}$ and embedded in paraffin. 5- $\mu$ sections of all specimens were cut and mounted on glass slides that had been coated with a chrome-alum mixture.

Deparaffinization was accomplished with Americlear (American Scientific Products, Inc., McGaw Park, IL) and absolute alcohol, and endogenous peroxidase was blocked by incubation in methanol- $0.6 \%$ hydrogen peroxide for $30 \mathrm{~min}$. The sections were rehydrated in graded alcohols, distilled water, and PBS (pH 7.4).

Primary antibodies to factor VIII-related antigen and vimentin were applied for $18 \mathrm{~h}$ at $4^{\circ} \mathrm{C}$ in moisture chambers. Localization of antibody binding was visualized with the avidin-biotin-peroxidase complex $(\mathrm{ABC})$ procedure, as described previously (10), using 3,3'diaminobenzidine hydrochloride $(0.25 \mathrm{mg} / \mathrm{ml}$ with $0.003 \%$ hydrogen peroxide) as the chromogen. Sections were then immersed briefly in $0.125 \%$ osmium tetroxide (wt/vol), counterstained with Harris hematoxylin, and coverslipped with a synthetic mounting medium.

Positive controls consisted of unrelated tissue-banked specimens known to contain the determinants of interest; "internal controls" such as bronchial epithelium and large pulmonary blood vessels were also assessed to verify methodologic integrity. Sections of all study cases were also labeled with $\mathrm{ABC}$ after substitution of nonimmune mouse ascites fluid for primary antibodies; these served as negative controls. All immunohistochemical preparations were reviewed and interpreted by one observer.

\section{Bronchoalveolar lavage}

Bronchoalveolar lavage was performed in order to obtain fluid from the air-lung interface as previously described (11). In acute lung injury patients receiving mechanical ventilation, bronchoscopy was performed through an endotracheal tube using an appropriate adapter. All patients received $100 \%$ oxygen during the procedure, and oxygen saturation and electrocardiogram were continuously monitored. The procedure was terminated if the oxygen saturation fell below $90 \%$ for more than $1 \mathrm{~min}$. Up to three separate anatomic sites were sampled in each patient with acute lung injury. In patient controls, after local anesthesia of the upper airway, the bronchoscope was wedged in a peripheral bronchus and five, $20 \mathrm{ml}$ aliquots of $0.9 \%$ saline were instilled and removed by gentle suction. Up to three separate anatomic locations were sampled in each patient. In a subset of acute lung injury patients who died from respiratory insufficiency, whole lung lavage was performed within $2 \mathrm{~h}$ of death ex vivo. Whole lung lavage was performed by cannulating the mainstem bronchus with plastic tubing followed by the instillation of sterile PBS $\left(30 \mathrm{~cm} \mathrm{H}_{2} \mathrm{O}\right.$ pressure). Fluid was recovered by gravity flow.

\section{Processing of bronchoalveolar lavage specimens}

Recovered bronchoalveolar lavage effluent was separated from cells by centrifugation $(600 \mathrm{~g} \times 15 \mathrm{~min})$. The cell free lavage effluent was either aliquoted and stored at $-70^{\circ} \mathrm{C}$ before assay, or kept at $4^{\circ} \mathrm{C}$ if the assay was to be performed immediately. Protein concentration of cell free lavage effluent was determined using a colorimetric assay (Pierce Chemical Co., Rockford, IL), and albumin concentration was quantified by ELISA as previously described (12).

\section{Biological assay of lavage fluid}

The bioassays used were chosen to assess two of the cellular responses integral to the process of angiogenesis: $(a)$ endothelial cell migration, and $(b)$ the formation of capillary networks in vivo $(6,7)$. To identify the presence of angiogenesis bioactivity, lavage effluent from all patients was analyzed using an endothelial cell migration assay. Confirmation of angiogenesis bioactivity detected in the migration assay was performed using an in vivo angiogenesis assay.

\section{MIGRATION ASSAY}

Endothelial cell migration was assessed in a modified Boyden chemotaxis chamber (Nucleopore, Pleasanton, CA), as previously described $(13,14)$. To ensure the generalizability of the bioassay results, both microvascular and large vessel endothelial cells were used in the chemotaxis assay. Rabbit wound microvascular endothelial cells were isolated from sponges implanted in the backs of New Zealand white rabbits by modifying the isolation procedure used to harvest rabbit brain capillary endothelial cells, as described (14). Bovine pulmonary artery endothelial cells were isolated by gentle scraping of the luminal surface of the pulmonary artery and cultured in M199+20\% FCS in $25 \mathrm{~cm}^{2}$ Primaria flasks (Becton Dickinson and Co., Lincoln Park, NJ) $\left(37^{\circ} \mathrm{C}\right.$; $5 \% \mathrm{CO}_{2}, 95 \%$ air). Pulmonary artery endothelial cells, when confluent, displayed typical cobblestone morphology using phase contrast microscopy. Cell identity was confirmed by anti-factor VIII staining and by specific labeling, using a fluorescent acetylated LDL probe as described $(15,16)$.

Briefly, for each study, $26 \mu \mathrm{l}$ of the test fluid at various concentrations were placed in the wells of the lower chamber of the chemotaxis apparatus. $45 \mu \mathrm{l}$ of the cell suspension $(750,000$ cells/ml in M199 $+0.2 \%$ lactalbumin) were placed in the upper wells, which were separated from the lower chamber by a fibronectin-coated $(1 \mu \mathrm{g} / \mathrm{ml}, 30 \mathrm{~min}$ each side), porous (8- $\mu \mathrm{m}$ diameter pores) polycarbonate filter (Nucleopore). The chemotaxis chambers were incubated $\left(37^{\circ} \mathrm{C}, 4 \mathrm{~h} ; 95 \%\right.$ air, $5 \% \mathrm{CO}_{2}$ ) permitting cell migration to occur. Migration was quantified as the number of cells on the lower side of the filter per $100 \times$ field. Degranulated platelet lysate served as a positive control and M199 $+0.2 \%$ lactalbumin as a negative control.

\section{IN VIVO ANGIOGENESIS ASSAY}

Confirmation of angiogenesis bioactivity detected in the migration assay was performed by assessing the ability of a test sample to induce neovascularization in the normally avascular cornea of the New Zealand white rabbit. To accomplish this, the test fluid was introduced into the stroma of the cornea and vascular ingrowth from the limbus into the cornea was assessed as previously described (17). Bronchoalveolar lavage effluent or partially purified angiogenesis bioactivity was clarified by centrifugation $(10,000 \mathrm{rpm} \times 5 \mathrm{~min})$, dialyzed against buffer (7.5 mM NaCl, $5.0 \mathrm{mM} \mathrm{NaPO}_{4}, \mathrm{pH} 7.4$ ), and concentrated 10 to 20 fold by speed evaporation (Speed Vac Concentrator; Savant Instruments, Farmingdale, NY). The concentrated sample was resuspended in $25 \mu$ l of sterile distilled $\mathrm{H}_{2} \mathrm{O}$, incorporated into an equal volume of sterile Hydron casting solution, and allowed to solidify. The Hydron pellet containing the test fluid was introduced into a pouch formed in the corneal stroma. Hydron containing buffer served as a negative control. The corneas were examined every other day to monitor for infection and capillary growth. Photographs were taken on day 2 and day 7 to record the results, and some animals were killed on day 2 and the remainder on day 7 to evaluate the corneas histologically for inflammation. The corneas were removed and fixed in PBS containing 10\% formalin. Paraffin sections were prepared and stained with hematoxylin and eosin for histologic examination of new vessel growth.

\section{Biophysical and biochemical characterization of the angiogenesis bioactivity}

After each procedure characterizing the angiogenesis bioactivity, the migration assay was used to identify the bioactivity. In some cases, as indicated, results were confirmed using the in vivo angiogenesis assay. The biophysical properties assessed included: 
(a) solubility in nonpolar solvents (1:1 ethyl acetate); (b) heat stability $\left(100^{\circ} \mathrm{C}, 15 \mathrm{~min}\right) ;(c)$ acid stability $(\mathrm{pH} 3,12 \mathrm{~h})$; and $(d)$ protease sensitivity (trypsin, $0.2 \mathrm{mg} / \mathrm{ml}, 30 \mathrm{~min}, 37^{\circ} \mathrm{C}$; inactivated with a twofold molar excess of soybean trypsin inhibitor).

Biochemical characterization of the angiogenesis bioactivity consisted of sequential chromatography using heparin affinity, ion exchange, and gel filtration. The starting material for these studies was 1 liter of lavage fluid obtained from whole lung lavage of postmortem lungs (processed in $\leq 2 \mathrm{~h}$ ). All procedures were carried out using this material and confirmed in other routinely obtained lavage fluid as quantities permitted.

One class of endothelial cell growth factors, the fibroblast growth factors, avidly binds heparin (18-20). To isolate members of this class, bronchoalveolar lavage fluid was applied to a heparin-sepharose column in equilibration buffer $(0.05 \mathrm{M} \mathrm{NaCl}, 0.01 \mathrm{M}$ Tris, $\mathrm{pH}$ 7.4). The column was developed stepwise with buffers of increasing ionic strength $(0.5 \mathrm{M} \mathrm{NaCl}, 1 \mathrm{M} \mathrm{NaCl}, 1.5 \mathrm{M} \mathrm{NaCl}, 2 \mathrm{M} \mathrm{NaCl})$. Fractions were dialyzed against PBS before the assay. Bioactivity binding to heparin-sepharose was further analyzed by SDS-PAGE and Western blot analysis (see below).

Bioactive fractions of lavage fluid failing to bind to heparin-sepharose were directly applied in equilibration buffer $(0.125 \mathrm{M} \mathrm{NaCl}, 0.01 \mathrm{M}$ Tris, $\mathrm{pH}$ 7.4) to an anion exchange resin (diethylamino ethyl sepharose; [DEAE-S]). The column was developed in a stepwise fashion with buffered $\mathrm{NaCl}$ solutions $(0.01 \mathrm{M}$ Tris, $\mathrm{pH} 7.4)$ of increasing ionic strength: $0.25 \mathrm{M} \mathrm{NaCl}, 0.50 \mathrm{M} \mathrm{NaCl}, 0.75 \mathrm{M} \mathrm{NaCl}, 1.0 \mathrm{M} \mathrm{NaCl}$. Fractions were dialyzed against PBS before the assay.

The DEAE-S fractions with biological activity were further purified using a strong anion exchange resin (Mono Q column; Pharmacia, Inc. Piscataway, NJ) and a linear gradient as dictated by the results of the stepwise elution. Active fractions were dialyzed and applied in starting buffer $(0.125 \mathrm{M} \mathrm{NaCl}, 0.01 \mathrm{M}$ Tris, $\mathrm{pH} 7.4)$. The column was developed with a linear salt gradient $(0.125-0.300 \mathrm{M} \mathrm{NaCl})$. Fractions were directly examined for biological activity without further handling.

To obtain an estimate of molecular mass, the Mono $Q$ fractions with biological activity were applied to a gel filtration column (Superose $12,10 \times 300 \mathrm{~mm}$, flow rate $=0.5 \mathrm{ml} / \mathrm{min}$; Pharmacia). The column was developed with PBS, pH 7.4, containing $10 \%$ acetonitrile, to minimize nonspecific interaction with the gel filtration matrix. Pilot studies indicated that $10 \%$ acetonitrile had no effect on the bioactivity in the chemotaxis assay. Molecular weight standards included: human IgG (166 kD), human serum albumin (66 kD), ovalbumin $(44 \mathrm{kD})$, soybean trypsin inhibitor $(21 \mathrm{kD})$, and aprotinin $(6.5 \mathrm{kD})$. Fractions were directly examined for biological activity. Of note, instability of the bioactivity in higher concentrations of organic buffer ( $>30 \%$ acetonitrile) precluded further purification by reverse phase chromatography.

\section{ADHESION ASSAY}

Directed endothelial cell migration can occur as a result of movement of endothelial cells toward a positive chemical gradient (chemotaxis) or as a result of contact with proteins that promote cellular adhesion (haptotaxis) $(14,21,22)$. To determine if the angiogenesis bioactivity identified by the chemotaxis assay promoted cellular attachment, adhesion of endothelial cells to substratum-bound proteins was determined using a standard adhesion assay as described (23). Test proteins used in the adhesion assay were prepared at various concentrations in Vollers buffer ( $15 \mathrm{mM} \mathrm{Na}_{2} \mathrm{CO}_{3}$ and $34.8 \mathrm{mM} \mathrm{NaHCO}_{3}, \mathrm{pH} 9.6$ ), as follows: (a) positive controls, soluble type IV collagen, fibronectin; $(b)$ negative control, bovine serum albumin; and (c) test protein, partially purified lavage angiogenesis factor (active fractions after gel filtration).

\section{WESTERN BLOT ANALYSIS}

To analyze the heparin binding bioactivity for the presence of the well established endothelial cell growth factor, bFGF, Western blot analysis was performed. Proteins were electrophoresed in $15 \%$ polyacrylamide gels containing SDS according to the method of Laemmli (24). The samples were mixed $(2: 1$, vol/vol) with nonreducing sample buffer (20\% glycerol, $2.3 \%$ sodium dodecyl sulfate, $0.625 \mathrm{M}$ Tris base, $0.001 \%$ bromphenol blue, $\mathrm{pH} 6.8$ ) and loaded (up to $50 \mu \mathrm{g}$ total protein) into each lane. Proteins were electrophoresed $\left(3 \mathrm{~h}, 22^{\circ} \mathrm{C}\right)$ by applying 15 mA of constant current (ECPS 3000/150; Pharmacia). For transfer of proteins, gels were overlayed with a $0.2 \mu \mathrm{m}$ nitrocellulose membrane, submerged in transfer buffer ( $25 \mathrm{mM}$ Tris-base, $192 \mathrm{mM}$ glycine, $20 \%$

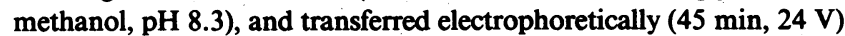
using a tank-type plate electrode blotter (Idea Scientific Co., Minneapolis, MN). After electrophoretic transfer of proteins, the nitrocellulose blot was dried and developed as described for the immunoblot assay (see below).

\section{IMMUNOBLOT ASSAY}

An immunoblot assay was used to quantify bFGF in selected column fractions during the purification procedures, as previously described (25). The primary antibody used in the immunoblot assay was a rabbit anti-bovine bFGF antibody (R\&D Systems Minneapolis, MN; $20 \mu \mathrm{g} /$ $\mathrm{ml}$ ) and the secondary antibody was swine anti-rabbit IgG coupled to horseradish peroxidase (Dako Corp., Santa Barbara, CA; 1:250 dilution in TTBS, $150 \mathrm{mM} \mathrm{NaCl}, 100 \mathrm{mM}$ Tris, $0.05 \%$ Tween 20). To eliminate cross-reactivity between the secondary antibody and human IgG in the processed lavage effluent, before incubation the secondary antibody was preabsorbed $\left(1 \mathrm{~h}, 22^{\circ} \mathrm{C}\right)$ with TTBS containing $1 \mathrm{mg} / \mathrm{ml}$ nonfat dry milk, $1 \mathrm{mg} / \mathrm{ml} \mathrm{BSA}$, and $1 \mathrm{mg} / \mathrm{ml}$ human IgG. Recombinant bFGF (R\&D Systems) served as a positive control.

\section{Statistical methods}

Groups were compared using a chi-square test for proportions.

\section{Results}

\section{Analytical results of bronchoalveolar lavage}

Bronchoalveolar lavage was performed in critically ill, mechanically ventilated patients and patient controls without complications. For the lung injury patients, results for range and median cell counts $(\mathrm{RBC}=$ range 0 to 24,000 cells $/ \mu \mathrm{l}$, median 3,200 cells $/ \mu \mathrm{l} ; \mathrm{WBC}=$ range 10 to $1,680 \mathrm{cells} / \mu \mathrm{l}$, median 140 cells $/ \mu \mathrm{l})$, differential cell counts $(\mathrm{M} \varnothing=12 \pm 8 \%, \mathrm{~N}$ $=88 \pm 9 \%)$ as well as lavage fluid total protein $(689 \pm 397 \mu \mathrm{g} /$ $\mathrm{ml})$, and albumin $(321 \pm 264 \mu \mathrm{g} / \mathrm{ml})$ concentrations were similar to previous reports $(26,27)$. (Values are reported as mean \pm standard deviation.) The overall mortality of our patient population was $44 \%$. Therefore, our study group had a degree of lung injury comparable to those described by other investigators. All values for patient controls fell within established norms (28) (data not shown).

\section{Histologic and immunohistochemical results}

All autopsy tissues from fatal cases of acute lung injury showed diffuse damage to alveolar lining epithelium, with foci of type II epithelial cell hyperplasia. The interstitium was widened irregularly by loose fibrovascular tissue, which contained capillary-sized blood vessels, surrounded by bland, fusiform, fibroblast-like cells. Remnants of intra-alveolar fibrin membranes were also observed. Multifocally, the interstitial fibrovascular (granulation) tissue protruded into alveoli, leaving only a narrow rim of airspace around it. Rare extravasated RBCs were apparent at these sites, as were scattered chronic inflammatory cells. There was no evidence of bronchiolitis obliterans or inflammatory change in large pulmonary blood vessels. Control specimens were microscopically unremarkable in all instances.

Immunohistochemically, in ARDS specimens, small capillary-sized blood vessels labeled by anti-factor VIII-related antigen (Fig. 1) were present in intraalveolar fibrovascular protrusions. In addition, vimentin was intensely expressed in fibro- 


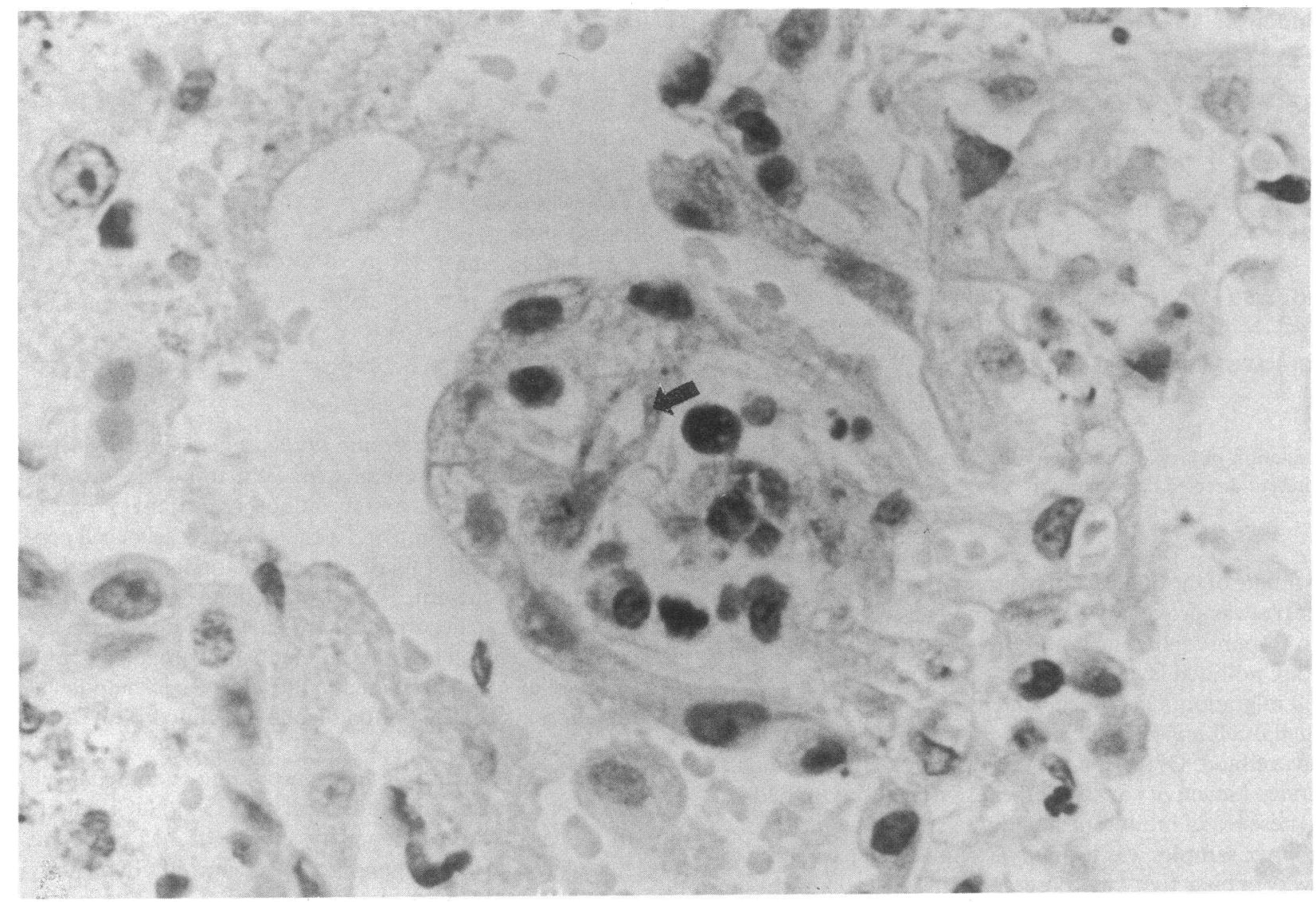

Figure 1. Immunoreactivity for factor VIII-related antigen within the endothelial cells of intra-alveolar capillaries in autopsy lung from a fatal case of ARDS. The capillaries (arrow) are supported by a loose fibrovascular matrix which protrudes from the interstitium into the airspace. Shown is a bud of granulation tissue replacing alveolar airspace (magnification, 250) (anti-factor VIII-related antigen/ABC Immunostain).

blast-like interstitial cells, vascular endothelium, and supporting stromal tissue of the lung, and it highlighted the contours of small capillary-sized blood vessels in intra-alveolar granulation tissue. Specimens of normal control lung failed to exhibit the presence of intra-alveolar fibrovascular protrusions or interstitial granulation tissue. All external and internal controls stained appropriately.

\section{Evaluation of lavage effluent for angiogenesis bioactivity}

In vitro migration. Endothelial cell migration toward an angiogenic stimulus is one of the principal cellular processes associated with new capillary growth in vivo. When lavage fluid from patients with acute lung injury was tested for its ability to stimulate endothelial cell migration, samples from 18 of 25 patients with acute lung injury $(72 \%)$ stimulated the migration of pulmonary artery endothelial cells (Fig. $2 A$ ). It should be noted that no routinely assessed clinical parameters, including disease severity, clinical course, or outcome, were found to distinguish those patients' samples with angiogenesis bioactivity from those without demonstrable bioactivity. In contrast, none of the samples from patient controls stimulated endothelial cell migration $(P<0.01)$. Because the likely target cells in vivo are microvascular endothelial cells, a subset of the positive specimens stimulating pulmonary artery endothelial cell migration was assessed for bioactivity using capillary endothelial cells. Of note, consistent with the results using large vessel endothelial cells, all of the lavage samples from patients with acute lung injury $(n=9)$, and none of the samples from patient controls $(n=4)$, stimulated microvascular endothelial cell migration $(P<0.01$; Fig. $2 B$ ). Checkerboard analysis revealed that endothelial cell migration induced by lavage fluid was due both to directed cell migration as well as random migration (Fig. 3).
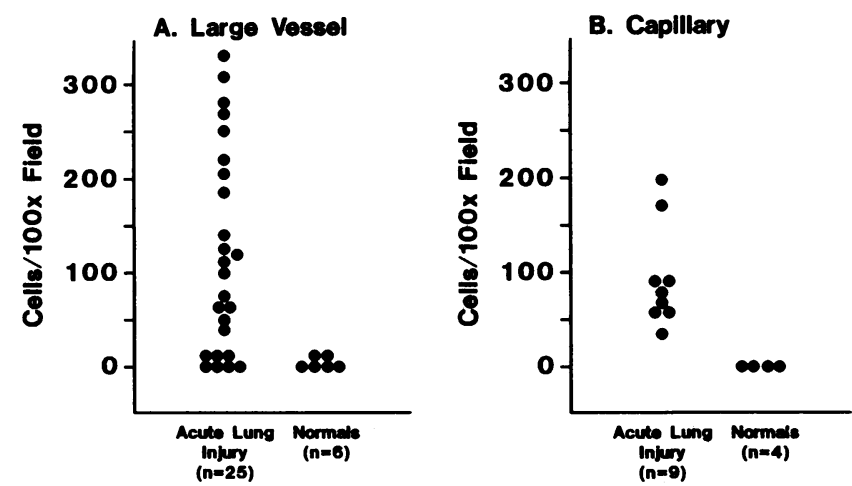

Figure 2. Endothelial cell migration in response to bronchoalveolar lavage fluid. Undiluted bronchoalveolar lavage fluid obtained from patients with acute lung injury or normal individuals was evaluated for its ability to induce endothelial cell migration in a modified Boyden chamber apparatus. Shown is (A) large vessel and (B) capillary endothelial cell migration quantified as the number of cells migrating per $100 \times$ field. 


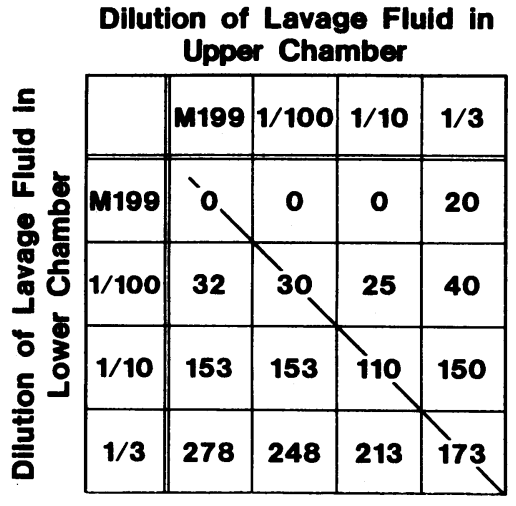

Figure 3. Checkerboard analysis of endothelial cell migration in response to bronchoalveolar lavage fluid from patients with acute lung injury. The upper and lower chamber of the assay apparatus was filled with varying dilutions of lavage fluid from patients with acute lung injury as indicated. Shown is the number of endothelial cells migrating per $100 \times$ field for

each combination of lavage fluid dilutions. The values below the diagonal represent directed cell migration.

An estimate of the quantity of the migration bioactivity in a given sample was provided by evaluating endothelial cell migration in response to defined dilutions of bronchoalveolar lavage fluid. Undiluted lavage fluid stimulated maximum endothelial cell migration. On average, the half-maximum increase in endothelial cell migration occurred in response to a 1:3 dilution of lavage fluid. Of note, none of the patient control fluids demonstrated bioactivity at any of the tested dilutions. In addition, the presence of inhibitors of endothelial cell migration in patient control samples was formally excluded when quantitative recovery of bioactivity was observed using two approaches: (a) addition of the positive control (platelet lysate) in parallel assays, and $(b)$ equal mix experiments with selected acute lung injury patient samples (data not shown). Likewise, in selected acute lung injury samples in which endothelial cell migration was not observed, the lavage fluid was studied using an equal mix experiment in which the positive control was added to the lavage sample. Using this approach, significant inhibition was not observed.

In vivo neovascularization. Confirmation of the angiogenesis bioactivity detected in the migration assay was obtained by the ability of selected bioactive samples to induce corneal neovascularization. When concentrated lavage fluid from the patients demonstrating the greatest amount of in vitro chemotactic bioactivity $(n=2)$ was implanted in the avascular cornea of rabbits, both samples induced capillary growth. Histologically, inflammation characterized by accumulation of macrophages into the inflammatory site was associated with the new microvessels, leaving open the possibility that the lavage fluid did not induce angiogenesis directly, but rather by inducing an inflammatory response. Significantly, no growth of new vessels was induced by lavage fluid from patient controls $(n=2)$.

Biophysical properties of the angiogenesis bioactivity. Biophysical characterization of the angiogenesis bioactivity revealed properties expected of a peptide(s). The bioactivity was destroyed by boiling $\left(100^{\circ} \mathrm{C}, 15 \mathrm{~min}\right)$, acidic conditions ( $\left.\mathrm{pH} 3\right)$, and protease exposure (trypsin $0.2 \mathrm{mg} / \mathrm{ml}, 30 \mathrm{~min}, 37^{\circ} \mathrm{C}$ ). Soybean trypsin inhibitor was used to neutralize trypsin activity. When soybean trypsin inhibitor was mixed equally with the positive control, platelet releasate, chemotactic activity was preserved. In addition, the bioactivity was not extracted into nonpolar solvents (Table I). These results served as the starting point for further purification and characterization.
Table I. Biophysical Characterization of the Angiogenesis Bioactivity

\begin{tabular}{lc}
\hline \multicolumn{1}{c}{ Treatment } & $\begin{array}{c}\text { Number of endothelial cells } \\
\text { migrating/100 } \times \text { field }\end{array}$ \\
\hline No treatment & 150 \\
Aqueous phase & 125 \\
Lipid phase & 0 \\
Trypsin digestion & 0 \\
Acid (pH 3) & 0 \\
Heat & 0 \\
\hline
\end{tabular}

Biochemical characterization of the angiogenesis bioactivity. A characteristic of several extracellular matrix proteins (e.g., fibronectin, laminin, and thrombospondin) that promote cell migration and adhesion and a class of endothelial cell peptide growth factors (fibroblast growth factor family) is their ability to bind to heparin. When bronchoalveolar lavage effluent was applied to heparin-sepharose, $30 \%$ of the angiogenesis bioactivity bound at low ionic strength and remained bound up to $1.5 \mathrm{M} \mathrm{NaCl}$, as determined in the large vessel endothelial cell migration assay. The bound bioactivity eluted from heparin at $2 \mathrm{M} \mathrm{NaCl}$.

Among the characterized heparin binding endothelial cell growth factors, only bFGF binds avidly at $1.5 \mathrm{M} \mathrm{NaCl}$. Therefore, the heparin binding bioactivity eluting at $2 \mathrm{M} \mathrm{NaCl}$ was subjected to Western blot analysis using an anti-bFGF primary antibody. An 18-kD band comigrating with a bFGF standard (recombinant bFGF) was identified (Fig. 4). In addition, a lower molecular weight $(\sim 12$ to $13 \mathrm{kD})$ bFGF immunoreactive band was present. No bFGF immunoreactivity was demonstrated in the heparin-sepharose unbound fraction, nor in any of the fractions eluting at lower ionic strengths (data not shown).

The majority (70\%) of the angiogenesis bioactivity failed to bind heparin, and was evaluated for its ability to bind to ion-exchange resins. $50 \%$ of the bioactivity bound to the weak anion

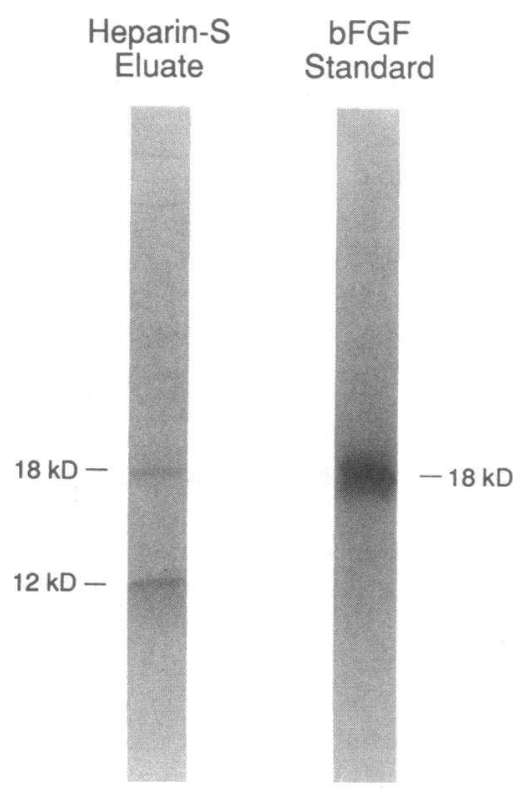

Figure 4. Western blot analysis of the heparin binding bioactivity. Bioactive material eluted from heparin sepharose $(2 \mathrm{M} \mathrm{NaCl})$ was subjected to SDSPAGE (15\%) and transferred to nitrocellulose membranes. Shown are transferred proteins recognized by anti-bFGF polyclonal antibody. A recombinant bFGF standard was included as a standard. 
exchange resin (diethylamino ethyl sepharose; $0.05 \mathrm{M} \mathrm{NaCl}$, $0.01 \mathrm{M}$ Tris, $\mathrm{pH}$ 7.4), eluting at $0.25 \mathrm{M} \mathrm{NaCl}$. Chromatographic analysis of the bioactivity using a strong anion exchanger (Mono Q column; Pharmacia) and a linear salt gradient revealed a single peak of bioactivity eluting from the column at $\sim 260 \mathrm{mM} \mathrm{NaCl}$ (Fig. 5).

Gel filtration chromatography of the Mono $Q$ peak was carried out to further purify the bioactivity and to obtain an estimate of its molecular weight. The endothelial cell migration bioactivity eluted just after the human IgG standard, corresponding to an approximate molecular weight of $150 \mathrm{kD}$ (Fig. 6).

The biochemical characteristics (heparin affinity, ion exchange properties) of the angiogenesis bioactivity were examined in relation to the timepoint in the clinical course that a patient was studied. The biochemical properties of the angiogenesis bioactivity present in bronchoalveolar lavage fluid obtained from acute lung injury patients early in their clinical course (days 2-4) were identical to those present in the lavage fluid obtained from patients later in their clinical course (days 10-21).

Biological properties of the 150-kD bioactivity. The molecular weight estimate of $150 \mathrm{kD}$ indicated that the angiogenesis bioactivity was larger than the majority of cellular-derived peptide growth factors. However, it fell within the range of a variety of extracellular matrix protein and degradation products that promote both endothelial cell migration and adhesion. Therefore, the $150-\mathrm{kD}$ bioactivity was evaluated for its ability to promote endothelial cell attachment. When a plastic substratum was coated with increasing concentrations of the 150$\mathrm{kD}$ peptide, there was a dose-dependent increase in endothelial cell adhesion (Fig. 7). Type IV collagen and fibronectin, two extracellular matrix proteins that promote endothelial cell adhesion in a dose-dependent fashion, were used as positive controls. Bovine serum albumin, which does not promote endothelial cell attachment, was used as a negative control. In mediating endothelial cell attachment the $150-\mathrm{kD}$ peptide was at least as potent as type IV collagen and one to two logs more potent than intact fibronectin.

Based on these results, it became apparent that the endothelial cell migration observed in response to crude lavage fluid

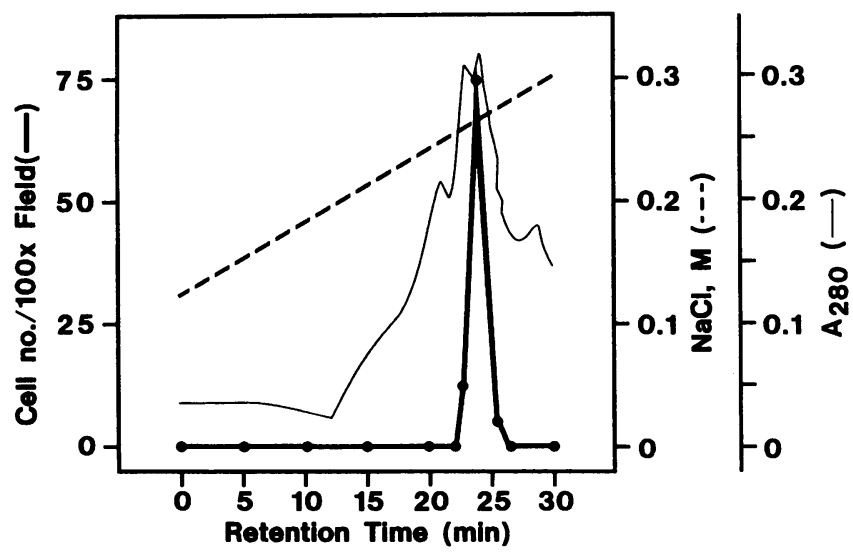

Figure 5. Anion exchange chromatography of the heparin sepharose unbound bioactivity. The bioactivity failing to bind heparin was applied to a Mono $\mathrm{Q}$ column, which was developed with a linear $\mathrm{NaCl}$ gradient. Shown is endothelial cell migration in response to undiluted aliquots from each column fraction.

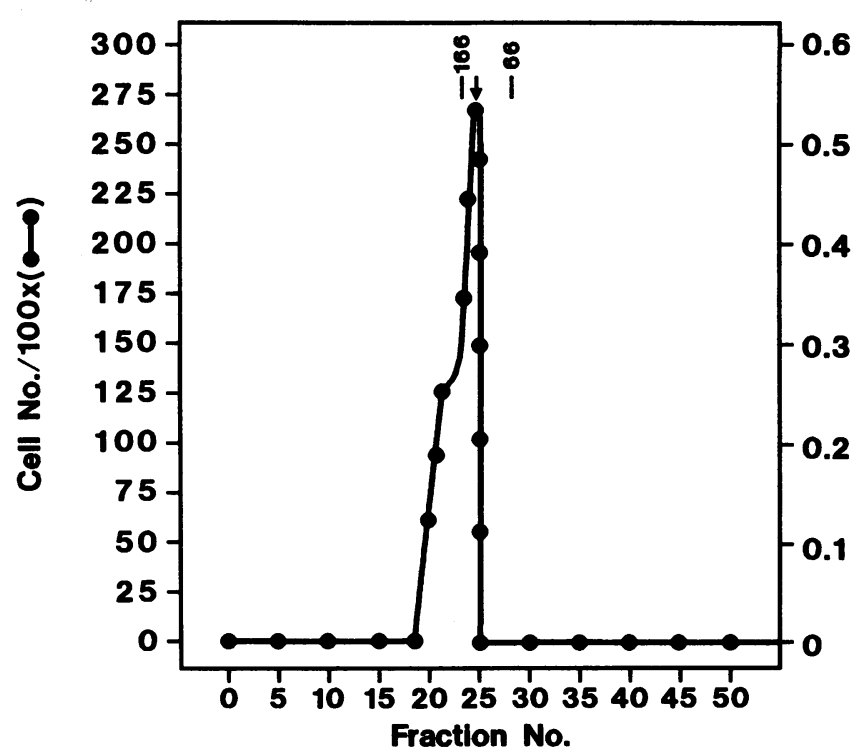

Figure 6. Gel filtration chromatography of the bioactivity. A 500- $\mu 1$ aliquot from the Mono $Q$ peak of bioactivity was applied to a Superose 12 column and developed in PBS, pH 7.4, $10 \%$ acetonitrile at 0.5 $\mathrm{ml} / \mathrm{min}$. Shown is endothelial cell migration in response to undiluted aliquots from each column fraction. The elution profile of two of the molecular weight standards is indicated: $\operatorname{IgG}(166 \mathrm{kD})$ and human serum albumin $(66 \mathrm{kD})$.

might have been dependent on the fibronectin used to coat the polycarbonate filters. Therefore, the migration assay was repeated using the $150-\mathrm{kD}$ bioactivity and filters rinsed in PBS but not coated with fibronectin. Significantly, concentrationdependent endothelial cell migration occurred in response to the $150-\mathrm{kD}$ bioactivity, indicating that the observed effects were not dependent on the presence of exogenous fibronectin.

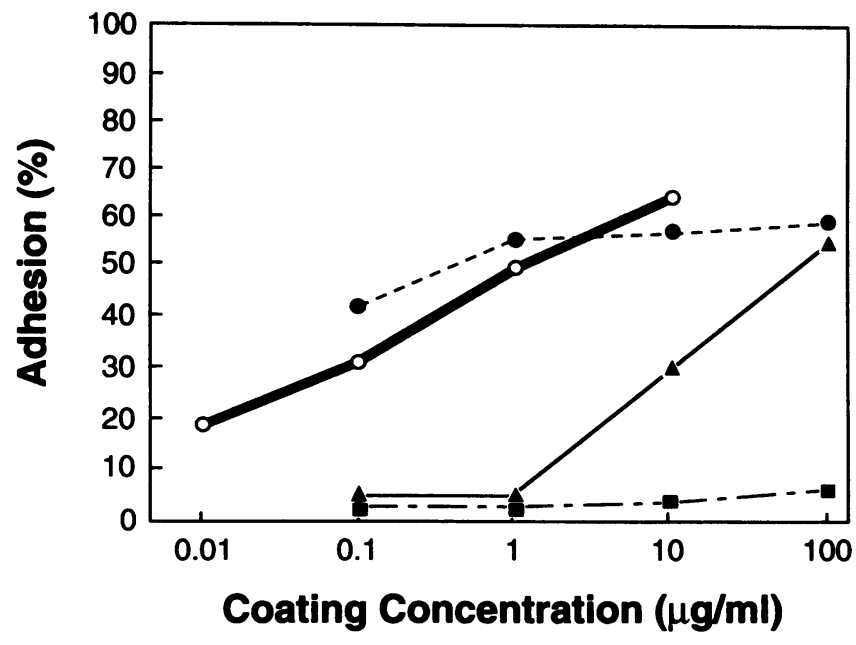

Figure 7. Endothelial cell attachment in response to the 150-kD bioactivity. Tissue culture wells were coated with soluble test proteins or controls and were examined for their ability to mediate the attachment of radiolabeled endothelial cells. Shown is the endothelial cell adhesion in response to increasing concentrations of the $150-\mathrm{kD}$ peptide (O); positive control proteins, type IV collagen ( $(\bullet)$ and fibronectin (₫); or the negative control protein, BSA ( $($ ). Data is expressed as percentage adhesion $=[$ DPM attached/DPM added $] \times 100$. 
To plausibly be involved in neovascularization of the airspace after acute lung injury, the $150-\mathrm{kD}$ bioactivity should promote new capillary growth in vivo. When $\sim 10 \mathrm{ng}$ of the $150-\mathrm{kD}$ bioactivity was incorporated into Hydron and implanted in the avascular cornea of rabbits, new capillary growth was observed. Vessels were observed to be growing from the limbus to the Hydron pellet containing the $150-\mathrm{kD}$ angiogenesis bioactivity implanted within the corneal stroma. Notably, histological examination of the corneas on day 2 and 7 did not show the presence of an inflammatory infiltrate. Thus, partial purification of the angiogenesis bioactivity present in the crude lavage fluid removed proinflammatory molecules but preserved the angiogenesis activity. (Fig. 8, $A$ and $B$ ).

\section{Discussion}

Replacement of the alveolar airspace with granulation tissue is the central morphologic feature characterizing the lungs of patients dying after acute lung injury (4). Angiogenesis, a process consisting of endothelial cell migration and replication in response to a specific set of exogenous signals, is an integral feature of this granulation tissue formation. This study demonstrates the presence of growth regulatory signals recovered from the air-lung interface that have the ability to modulate endothelial cell function. Analysis of the angiogenesis bioactivity reveals the presence of two discrete moieties: $(a)$ an 18-kD heparin binding factor that appears to be identical to bFGF; and $(b)$ a $150-\mathrm{kD}$ factor that promotes endothelial cell migration and adhesion in a dose-dependent fashion in vitro, and induces the formation of microvessels in vivo.

\section{Wound repair: a paradigm for studying the granulation tissue response}

The primary tissue healing response to wounding is the formation of granulation tissue followed by epithelialization (29). When it occurs after a surface wound, the formation of granulation tissue is an adaptive response, bringing about closure of the wounded integument. However, when this highly conserved response to tissue injury occurs after disruption of the alveolar wall, the alveolar airspace fills with granulation tissue, obliterating the gas exchange apparatus. In this anatomic location, granulation tissue represents a maladaptive response to tissue injury, preventing effective gas exchange. Despite its adverse effect on lung function, the anatomic similarity of intraalveolar granulation to normal wound healing suggests that the extensive body of experimental information pertaining to wound healing may provide insight into the processes leading to intra-alveolar fibrosis following lung injury.

In the lung as in the skin, granulation tissue develops in a dynamic inflammatory milieu. Anatomically, the injured space is rapidly filled with the contents of degranulating platelets as well as plasma proteins $(30,31)$. These diverse elements develop into a provisional solid phase matrix. Migration of mesenchymal cells and microvascular endothelial cells into the wound space ensues, followed by formation of capillary networks and deposition of connective tissue elements (30-35). The anatomic precision of granulation tissue development likely depends on an orderly sequence of soluble and solid phase molecular signals coordinated both spatially and temporally. This may explain why no apparent relationship between disease severity or clinical course and the presence of angiogenesis activity was noted. In accord with the wound healing para- digm, this lack of relationship likely reflects the bias introduced by sampling a highly coordinated response at a single point in time. Longitudinal studies in which samples are sequentially obtained throughout the clinical course of lung injury will likely be required to show a relationship between angiogenic activity and the ultimate outcome. Nevertheless, this study has identified two signals that may have a role in the integrated response that leads to new blood vessel formation.

The process of angiogenesis, which is highly coordinated, is likely to be under the control of multiple molecular signals (36). New vessel formation involves the migration of endothelial cells toward a chemotactic stimulus. The migrating endothelial cells may then become aligned with one another and undergo replication to form a solid sprout (36-39). Based on this information and the results of this study it is useful to consider these signals in two groups: first, signals that function as classical peptide growth factors (e.g., bFGF), and second, signals that may function in solid phase as mediators of chemotaxis and adhesion (e.g., the $150-\mathrm{kD}$ peptide).

Peptide growth factors capable of stimulating endothelial cell growth, migration and/or angiogenesis. A defined set of peptide growth factors are capable of stimulating endothelial cell growth or migration and/or angiogenesis. In general they derive from both recruited inflammatory cells as well as parenchymal cells and include platelet-derived endothelial cell growth factor (40-42), and macrophage-derived transforming growth factor alpha (TGF $\alpha)(43,44)$. The relative importance of these two angiogenesis factors to the new vessel growth observed after acute lung injury remains uncertain.

One of the two moieties identified at the alveolar surface in this study, bFGF, has been reported to stimulate the replication of endothelial cells in vitro and new microvessel growth in vivo $(45,46)$. However, recent investigation has failed to show significant chemoattractant or in vivo angiogenic activity using recombinant bFGF (47). The results of our investigation indicate that lavage fluid eluted from heparin-sepharose with $2 \mathrm{M} \mathrm{NaCl}$ promotes large vessel endothelial cell migration and contains bFGF as identified by Western analysis. However, because bFGF was not purified, its role in endothelial cell migration remains inferential. Data linking bFGF with the process of wound healing include its ability to cause rapid neovascularization in the cornea and skin, as well as fibroplasia in the dermis after wounding $(45,48-50)$. These observations support the notion that bFGF is involved in neovascularization and wound repair.

The origin of biologically active bFGF in wounded tissue is incompletely understood. According to one hypothesis, bFGF produced by endothelial cells is released and sequestered in the basement membrane bound to heparan sulfate (and possibly other glycosaminoglycans) (51-54). In the inflammatory environment of wounded tissue, bFGF stored within the basement membrane is released enzymatically (e.g., plasmin or heparinase) where it can act on target microvascular cells to promote angiogenesis (53). While the origin of the bFGF recovered from the alveolar epithelial surface after acute lung injury remains to be determined, this study provides clear evidence that this known endothelial cell growth factor is present at a site where new blood vessels are forming.

Moieties mediating endothelial cell migration and adhesion. A significant portion of the identified angiogenesis bioactivity recovered from the lungs of patients after acute lung injury is a $150-\mathrm{kD}$ moiety that serves as a potent endothelial cell 

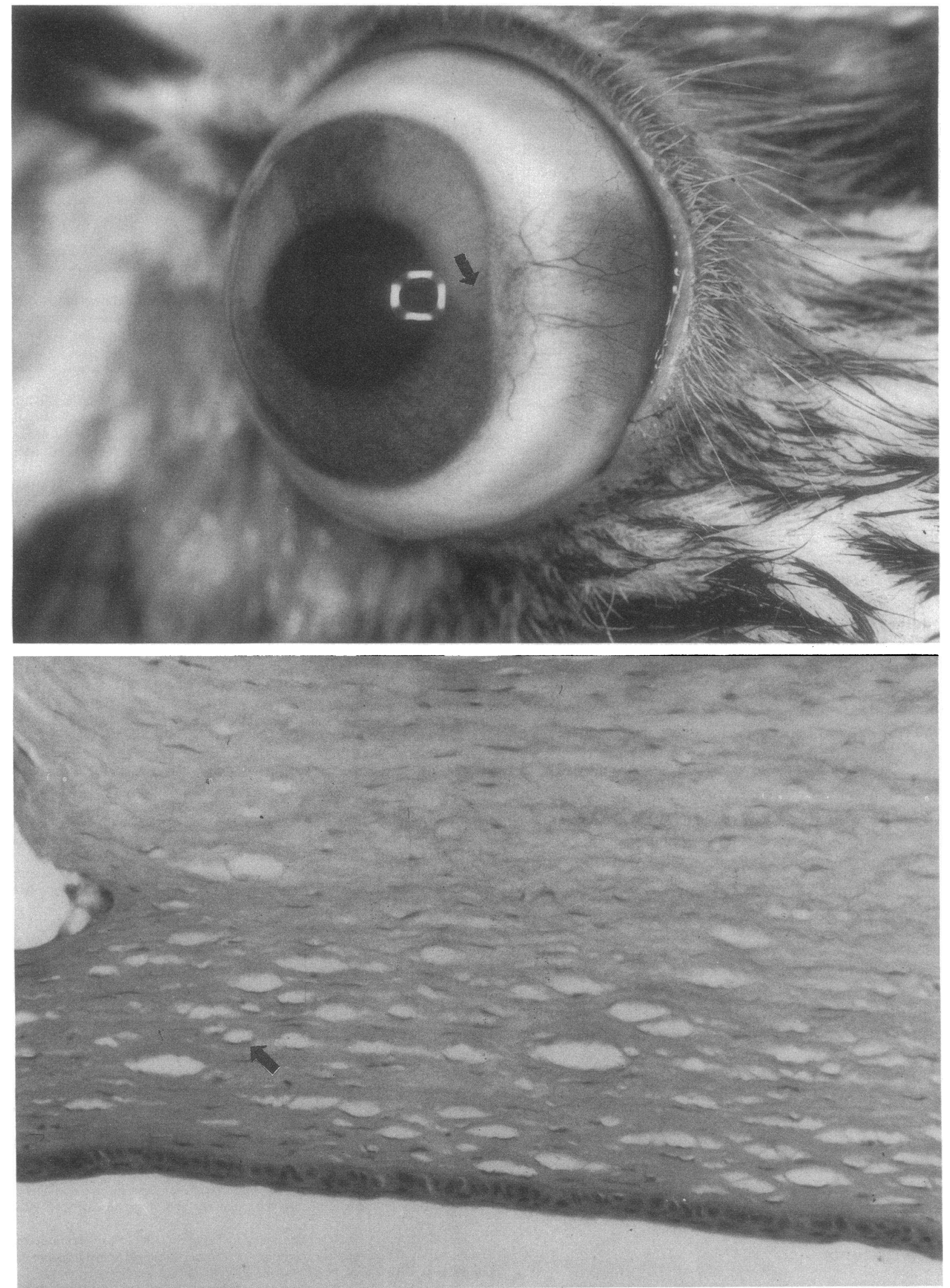

Figure 8. Corneal neovascularization. The 150-kD peptide was incorporated into sterile Hydron and implanted in the avascular cornea of a rabbit. At day 7 the eyes were examined. (A) In situ photograph showing new capillary growth (arrow). (B) Histology of cornea displaying new vessel growth (arrow) and lack of inflammatory cell infiltrate, $H$ and $E$, magnification, 200. 
migration factor and adhesogen. In addition, it promotes in vivo angiogenesis without causing inflammation. Its biochemical and biological properties suggest that it belongs to the family of extracellular matrix elements that promote endothelial cell attachment and migration. Several studies support the concept that components of the extracellular matrix and basement membrane are important modulators of those endothelial cell functions necessary for wound healing and new vessel growth and include Type IV collagen, thrombospondin, fibronectin, and/or fragments of fibronectin $(22,55-63)$.

Granulation of the alveolar airspace after acute lung injury: an hypothesis

Morphological studies of lung tissue after acute lung injury have documented the development and progression of granulation tissue as it obliterates the alveolar airspace. The anatomic similarity of this process to wound healing is striking. Disruption of the endothelial and epithelial cell layers and their basement membranes results in direct communication between the microvascular bed, interstitium, and alveolar airspace. As a consequence of this disruption, an intra-alveolar exudate rich in plasma proteins and cells, including platelets and macrophages, accumulates in the alveolar airspace (64). As the process evolves, the intra-alveolar exudate becomes organized by the migration of mesenchymal cells and endothelial cells from the interstitium through rents in the disrupted epithelial barrier into the airspace, resulting in the formation of granulation tissue within the airspace.

Based on the wound healing paradigm, both cellular and matrix derived protein products are capable of providing signals for neovascularization of the alveolar airspace after acute lung injury. One of these signals identified in this study is the endothelial cell growth factor bFGF. Possible cellular sources for bFGF include the alveolar macrophage and microvascular endothelial cells. In addition, it is possible that bFGF bound to basement membranes is released by molecules generated by the explosive inflammatory response associated with early phases of acute lung injury. A large portion of the angiogenesis bioactivity within the alveolar airspace after acute lung injury is an $\sim 150-\mathrm{kD}$ peptide. Although the precise chemical structure of the $150-\mathrm{kD}$ molecule angiogenesis factor remains to be established, its ability to promote cell attachment in addition to migration and angiogenesis in vivo, suggests that it belongs to the family of adhesogenic extracellular matrix elements. Candidate molecules include fragments of collagen (type IV) or fibronectin. Alternatively, it may be related to the cell-derived protein thrombospondin. Collectively these molecules share with the $150-\mathrm{kD}$ angiogenesis factor the ability to promote endothelial cell adhesion. Purification to homogeneity will be required for a definitive answer to its identity. Independent of the precise identity of this biologically-active moiety, this investigation supports the conclusion that neovascularization of the airspace, stimulated by at least two distinct peptide moieties, may be one of the central processes in the pathogenesis of intraalveolar granulation after acute lung injury.

\section{Acknowledgments}

The authors thank Barbara Penner and Mary Chelberg for their excellent technical assistance in the chemotaxis assay and adhesion assay, respectively. In addition, we thank Sylvia Danielson and Funmi Thompson for their excellent secretarial assistance.
This work was supported by grant F32 HL-08051-02 (to Dr. Henke) and grant RO1 HL-39833 (to Dr. Bitterman) from the National Institutes of Health.

\section{References}

1. Rinaldo, J. E., and R. M. Rogers. 1982. Adult respiratory distress syndrome. N. Engl. J. Med. 306:900-909.

2. Bachofen, M., and E. R. Weibel. 1977. Alterations of the gas exchange apparatus in adult respiratory insufficiency associated with septicemia. Am. Rev. Resp. Dis. 116:589-615.

3. Tomashefski, J. F., P. Davies, C. Boggis, R. Greene, W. M. Zapol, and L. M. Reid. 1983. The pulmonary vascular lesions of the adult respiratory distress syndrome. Am. J. Pathol. 112:112-126.

4. Fukuda, V., M. Ishizaki, Y. Masuda, G. Kimura, O. Kawanami, and Y. Masugi. 1987. The role of intraalveolar fibrosis in the process of pulmonary structural remodeling in patients with diffuse alveolar damage. Am. J. Pathol. 126:171-182.

5. Hasleton, P. S. 1983. Adult respiratory distress syndrome-a review. Histopathology (Oxf.) 7:307-332.

6. Folkman, J., and M. Klagsbrun. 1987. Angiogenic factors. Science (Wash. DC). 235:442-447.

7. Zetter, B. R. 1988. Angiogenesis: state of the art. Chest. 93:1595-1665.

8. Petty, T. L. 1982. Adult respiratory distress syndrome: definition and historical perspective. Clin. Chest Med. 3:3-8.

9. Pepe, P. E., R. T. Potkin, D. H. Reus, L. D. Hudson, and C. J. Carrico. 1982. Clinical predictors of the adult respiratory distress syndrome. Am. J. Surg. 144:124-129.

10. Hsu, S. M., L. Raine, and H. Fanger. 1981. Use of avidin-biotin-peroxidase complex $(\mathrm{ABC})$ in immunoperoxidase techniques: a comparison between ABC and unlabeled antibody (PAP) procedures. J. Histochem. Cytochem. 29:577-580.

11. Saltini, C., A. J. Hance, V. J. Ferrans, F. Bassett, P. Bitterman, and R. G. Crystal. 1984. Accurate quantification of cells recovered by bronchoalveolar lavage. Am. Rev. Respir. Dis. 130:650-658.

12. Davis, W. B., S. I. Rennard, P. B. Bitterman, and R. G. Crystal. 1983. Pulmonary oxygen toxicity: demonstration of early, reversible biologic changes in the human alveolar structures induced by hyperoxia. N. Engl. J. Med. 309:879-883.

13. Postlethwaite, A. E., R. Snyderman, and A. H. Kang. 1976. The chemotactic attraction of human fibroblasts to a lymphocyte-derived factor. J. Exp. Med. 144:1188-1203.

14. Banda, M. J., D. R. Knighton, T. K. Hunt, and Z. Werb. 1982. Isolation of a nonmitogenic angiogenesis factor from wound fluid. Proc. Natl. Acad. Sci. USA. 79:7773-7777.

15. Stein, O., and Y.Stein. 1980. Bovine aortic endothelial cells display macrophage-like properties towards acetylated ${ }^{125}$ I-labelled low density lipoprotein. Biochim. Biophys. Acta. 620:631-635.

16. Voyta, L. C., P. A. Netland, D. P. Via, and B. R. Zetter. 1984. Specific labelling of endothelial cells using fluorescent acetylated-low density lipoprotein. J. Cell Biol. 99:81a. (Abstr.)

17. Gimbrone, M. A., R. S. Cotran, S. B. Leapman, and J. Folkman. 1974. Tumor growth and neovascularization: an experimental model using the rabbit cornea. J. Natl. Cancer Inst. 52:413-419.

18. Shing, Y., J. Folkman, R. Sullivan, C. Butterfield, J. Murray, and M. Klagsbrun. 1984. Heparin affinity: purification of a tumor-derived capillary endothelial cell growth factor. Science (Wash. DC). 223:1296-1299.

19. Gospodarowicz, D., J. Cheng, G. Lui, A. Baird, and P. Bohlent. 1984. Isolation of brain fibroblast growth factor by heparin-sepharose affinity chromatography: identify with pituitary fibroblast growth factor. Proc. Natl. Acad. Sci. USA. 81:6963-6967.

20. Maciag, T., T. Mehlman, and R. Friesel. 1984. Heparin binds endothelial cell growth factor, the principal endothelial cell mitogen in bovine brain. Science (Wash. DC). 225:932-934.

21. Bowersox, J. C., and N. Sorgente. 1982. Chemotaxis of aortic endothelial cells in response to fibronectin. Cancer Res. 42:25-47.

22. Herbst, T. J., J. B. McCarthy, E. D. Tsilibary, and L. T. Furcht. 1988. Differential effects of laminin, intact type IV collagen, and specific domains of type IV collagen on endothelial cell adhesion and migration. J. Cell Biol. 106:1365-1373.

23. McCarthy, J. B., S. T. Hagen, and L. T. Furcht. 1986. Human fibronectin contains distinct adhesion-and motility-promoting domains for metastatic melanoma cells. J. Cell Biol. 102:179-188.

24. Laemmli, U. K. 1970. Cleavage of structural proteins during the assembly of the head of bacteriophage $\mathrm{T}_{4}$. Nature (Lond.). 227:680-685.

25. Wadzinski, M. G., J. Folkman, J. Sasse, K. Devey, D. Ingber, and M. Klagsbrun. 1986. Heparin-binding angiogenesis factors: detection by immunological methods. Clin. Physiol. Biochem. 5:200-209. 
26. Holter, J. F., J. E. Weiland, E. R. Pacht, J. E. Gadek, and W. B. Davis 1986. Protein permeability in the adult respiratory distress syndrome. Loss of size selectivity of the alveolar epithelium. J. Clin. Invest. 78:1513-1522.

27. Weiland, J. E., W. B. Davis, J. F. Holter, J. R. Mohammed, P. M. Dorinski, and J. R. Gadek. 1986. Lung neutrophils in the adult respiratory distress syndrome: clinical and pathophysiological significance. Am. Rev. Respir. Dis. 133:216-225.

28. Cherniak, R. M. (Coordinator). 1990. The BAL Cooperative Group Steering Committee. Bronchoalveolar lavage constituents in healthy individuals, idiopathic pulmonary fibrosis, and selected comparison groups. Am. Rev. Respir. Dis. 141(Suppl):S169-S202.

29. Leibovich, S. J., and D. M. Wiseman. 1988. Macrophages, wound repair and angiogenesis. Prog. Clin. Biol. Res. 266:131-146.

30. Hunt, T. K. 1976. Wound Healing: Disorders of Repair. Chirurgecom, Inc., South Plainfield, NJ. 99 pp.

31. Knighton, D. R., K. F. Ciresi, V. D. Fiegel, L. L. Austin and E. L. Butler 1986. Classification and treatment of chronic nonhealing wounds. Ann. Surg. 294:322-328.

32. Leibovich, S. J., and R. Ross. 1975. The role of the macrophage in wound repair. A study with hydrocortisone and anti-macrophage serum. Am. J. Pathol. 78:71-100.

33. Knighton, D. R., and V. D. Fiegel. 1989. Macrophage-derived growth factors in wound healing: regulation of growth factor production by the oxygen environment. Am. Rev. Respir. Dis. 140:1108-1111.

34. Hunt, T. K., D. R. Knighton, K. K. Thakral, W. H. Goodson III, and W. S. Andrews. 1984. Studies on inflammation and wound healing: angiogenesis and collagen synthesis stimulated in vivo by resident and activated wound macrophages. Surgery. 96:48-54.

35. Ross, R. 1968. The fibroblast and wound repair. Biol. Rev. 43:51-96.

36. Schoefl, G. I. 1963. Studies on inflammation. Growing capillaries: their structure and permeability. Virch. Arch. Pathol. Anat. Physiol. Klin. Med. 337:97-141.

37. Ausprunk, D. H., and J. Folkman. 1977. Migration and proliferation of endothelial cells in preformed and newly formed blood vessels during tumor angiogenesis. Miscrovasc. Res. 14:53-65.

38. Scholley, M. M., G. P. Ferguson, H. R. Seibel, J. L. Montour, and J. D. Wilson. 1984. Mechanisms of neovascularization. Vascular sprouting can occur without proliferation of endothelial cells. Lab. Invest. 51:624-634.

39. Presta, M., and D. B. Rifkin. 1988. New aspects of blood vessel growth: tumor and tissue derived angiogenesis factors. Haemostasis. 18:6-17.

40. Miyazono, K., T. Okabe, A. Urabe, F. Takaku, and C. H. Heldin. 1987. Purification and properties of an endothelial cell growth factor from human platelets. J. Biol. Chem. 262:4098-4103.

41. Miyazono, K., and C. H. Heldin. 1989. High-yield purification of plateletderived endothelial cell growth factor: structural characterization and establishment of a specific antiserum. Biochemistry. 28:1704-1710.

42. Ishikawa, F., K. Miyazono, U. Hellman, H. Drexler, C. Wernstedt, K Hagiwara, K. Usuki, F. Takaku, W. Risau, and C. H. Heldin. 1989. Identification of angiogenic activity and the cloning and expression of platelet-derived endothelial cell growth factor. Nature (Lond.). 338:557-562.

43. Schreiber, A. B., M. E. Winkler, and R. Derynck. 1986. Transformin growth factor- $\alpha$ : a more potent angiogenic mediator than epidermal growth factor. Science (Wash. DC). 232:1250-1253.

44. Rappolee, D. A., D. Mark, M. J. Banda, and Z. Werb. 1988. Wound macrophages express TGF- $\alpha$ and other growth factors in vivo: analysis by mRNA phenotyping. Science (Wash. DC). 241:705-712.

45. Shing, Y., J. Folkman, C. Haudenschild, D. Lund, R. Crum, and M.
Klagsbrun. 1985. Angiogenesis is stimulated by a tumor-derived endothelial cell growth factor. J. Cell. Biochem. 29:275-287.

46. Joseph-Silverstein, J., and D. B. Rifkin. 1987. Endothelial and growth factor and the vessel wall. Semin. Thromb. Haemostasis. 13:504-513.

47. Knighton, D. R., G. D. Philips, and V. D. Fiegel. 1990. Wound healing angiogenesis: indirect stimulation by basic fibroblast growth factor. J. Trauma. 30:S134-S144.

48. Dividson, J. M., M. Klagsbrun, K. E. Hill, A. Buckley, R. Sullivan, P. S. Brewer, and S. C. Woodward. 1975. Accelerated wound repair, cell proliferation, and collagen accumulation are produced by a cartilage-derived growth factor. $J$. Cell Biol. 100:1219-1227.

49. Hayek, A., F. L. Culler, G. M. Beattie, A. D. Lopez, P. Cuevas, and A. Baird. 1987. An in vivo model for study of the angiogenic effects of basic fibroblast growth factor. Biochem. Biophys. Res. Commun. 147:876-880.

50. Fredji-Reygrobellet, D., J. Plouet, T. Delagre, C. Baudouin, F. Bourret, and P. Lapalus. 1987. Effects of aFGF and bFGF on wound healing in rabbit corneas. Curr. Eye Res. 6:1205-1209.

51. Vlodavsky, I., J. Folkman, R. Sullivan, R. Fridman, R. Ishai-Michaeli, J. Sasse, and M. Klagsbrun. 1987. Endothelial cell-derived basic fibroblast growth factor: synthesis and deposition into subendothelial extracellular matrix. Proc. Natl. Acad. Sci. USA. 84:2292-2296.

52. Folkman, J., M. Klagsbrun, J. Sasse, M. Wadzinski, D. Ingber, and I. Vlodavsky. 1988. A heparin-binding angiogenic protein-basic fibroblast growth factor-is stored within basement membrane. Am. J. Pathol. 130:393-400.

53. Klagsbrun, M., and I. Vlodavsky. 1988. Biosynthesis and storage of basic fibroblast growth factor (BFGF) by endothelial cells: implication for the mechanism of angiogenesis. Prog. Clin. Biol. Res. 116:55-62.

54. Sommer, A., and D. B. Rifkin. 1989. Interaction of heparin with human basic fibroblast growth factor: protection of the angiogenic protein from proteolytic degradation by a glycoasminoglycan. J. Cell. Physiol. 138:215-220.

55. Saksela, O., and D. B. Rifkin. 1990. Release of basic fibroblast growth factor-heparan sulfate complexes from endothelial cells by plasminogen activator-mediated proteolytic activity. J. Cell Biol. 110:767-775.

56. Mosher, D. F. 1990. Physiology of thrombospondin. Annu. Rev. Med. 41:85-97.

57. Mosher, D. F., M. J. Doyle, and E. Jaffe. 1982. Synthesis and secretion of thrombospondin by cultured human endothelial cells. J. Cell Biol. 93:343-348.

58. Lawler, J., R. Weinstein, and R. O. Hynes. 1988. Cell attachment to thrombospondin: the role of arg-gly-asp, calcium, and integrin receptors. J. Cell Biol. 107:2351-2361.

59. Murphy-Ullrich, J. E., and M. Høök. 1989. Thrombospondin modulates focal adhesions in endothelial cells. J. Cell Biol. 109:1309-1319.

60. Raugi, G. J., J. E. Olerud, and A. M. Gown. 1987. Thrombospondin in early human wound tissue. J. Invest. Dermatol. 89:551-554.

61. Schwarz, U., D. Schuppan, I. Oberbăumer, R. W. Glanville, R. Deutzmann, R. Timpl, and K. Kühn. 1986. Structure of mouse type IV collagen. Eur. J. Biochem. 157:49-56.

62. Ruoslahti, E. 1988. Fibronectin and its receptors. Ann. Rev. Biochem. $57: 375-413$

63. Clark, R. A. F., P. DellaPelle, E. Manseau, J. M. Lanigan, H. F. Dvorak, and R. B. Colvin. Blood vessel fibronectin increases in conjunction with endothelial cell proliferation and capillary ingrowth during wound healing. $J$. Invest. Dermat. 79:269-276.

64. Kuhn III, C., J. Boldt, T. E. King, Jr, E. Crouch, T. Vortio, and J. A. McDonald. 1989. An immunohistochemical study of architectural remodeling and connective tissue synthesis in pulmonary fibrosis. Am. Rev. Respir. Dis. $140: 1693-1703$. 